\title{
Quantifying water erosion hazard in central Tunisia A case study: the Leben watershed
}

\author{
Chokri BEDOUI ${ }^{1^{*}}$ \\ ${ }^{1}$ Department of Geography, University of Sfax, Tunisia \\ Received 10 May 2018; Revised 22 October 2018; Accepted 3 November 2018 \\ *Correspondence to: Chokri BEDOUI, e-mail: Chokribedoui@outook.com
}

\begin{abstract}
This study was performed in order to quantify soil erosion in the arid lands of central Tunisia. To do this we used geographic information systems, remote sensing and the RUSLE prediction model. While the study area is characterized by reduced rainfall quantities and therefore a low $\mathrm{R}$ factor, other factors such as high soil erodibility, low vegetation cover and steep slopes resulted in locally high erosion rates. Indeed, the calculation of RUSLE factors revealed values between 0 and 731 tones $\times$ ha $^{-1} \times$ year $^{-1}$ with an average of 3.84 tones $\times$ ha $^{-1} \times y_{\text {ear }}{ }^{-1}$. Whereas most catchment lands have low levels, the relief surrounding the catchment has relatively high rates due to the high value of slopes, the skeletal soils that compose them, but also due to the absence of protection, reforestation or crop management. This study also showed that despite their small extension compared to the watershed, main streams sectors, and especially their banks, record the highest erosion rates mainly due to the flow accumulation in the downstream sectors. Relative protection of the piedmont, which has saved them from higher erosion, can only be considered efficient and sustainable if the upstream hillsides are also protected. The comparison with previous studies carried out in Tunisia shows similarities in the results of some of them, considering the natural geographical variation of the $R$ factor.
\end{abstract}

KEYWORDS

Water erosion; RUSLE; Tunisia; arid lands

\section{Introduction}

Soil water erosion is one of the main threats to arable lands sustainability. Tunisia is one of the Mediterranean countries most affected by this hazard. Combating land erosion in Tunisia is an old phe- nomenon and has become over time more widespread and more technical. Although studies on soil erosion have multiplied over time, the arid regions of Tunisia have not, to our knowledge, been of particular interest for this type of study. This is probably 
due to low precipitation that suggests low erosion, which this study is trying to contradict. Indeed, the scarcity of rainfall does not mean that central Tunisia lands are not affected by water erosion. On the contrary, precipitations in these regions follow wet cycles and less wet or even dry cycles. During wet periods, rainfalls often cause flooding with runoff and erosion values comparable to the more humid regions of northern Tunisia. Studies to quantify soil erosion began a few decades ago, but spatialization and mapping techniques were unreliable and resource-intensive. Today, this work is made easier by tools such as geographic information systems, remote sensing and digital models that can be integrated into them. This study intends to use these tools to attempt to quantify erosion based on the RUSLE model. This model is established on experimental studies plots and it is in continuous improvement (Wischmeier et al., 1965; Renard et al., 1997). The objective of such a model is not to stop erosion but to know the high-risk areas and then to act on the controllable factors such as slope length (shortening it by contouring or terracing), or by well choosing crops and protection types (Masson, 1971).

\section{Study area}

The study area, with an area of $1470 \mathrm{~km}^{2}$, is located in central Tunisia between $9^{\circ} 10^{\prime}$ to $9^{\circ} 50^{\prime} \mathrm{E}$ and $34^{\circ} 29^{\prime}$ to $34^{\circ} 51^{\prime} \mathrm{N}$ (Fig. 1). Altitudes vary from $115 \mathrm{~m}$ in the central plains to $986 \mathrm{~m}$ in the relief bordering the watershed. The Meloussi and Majoura mountains border the catchment on the north and west sides, the South Bouhedma Mountain and the Mehiri-Zebbeus mountain on the east side (Fig. 2). The major part of the basin corresponds on the contrary to vast plains which are disturbed only locally by Kodiat Ouled Amara plateau. These reliefs generally correspond to anticlines bordering two large synclines, partially separated to the west by a small anticline convexity.
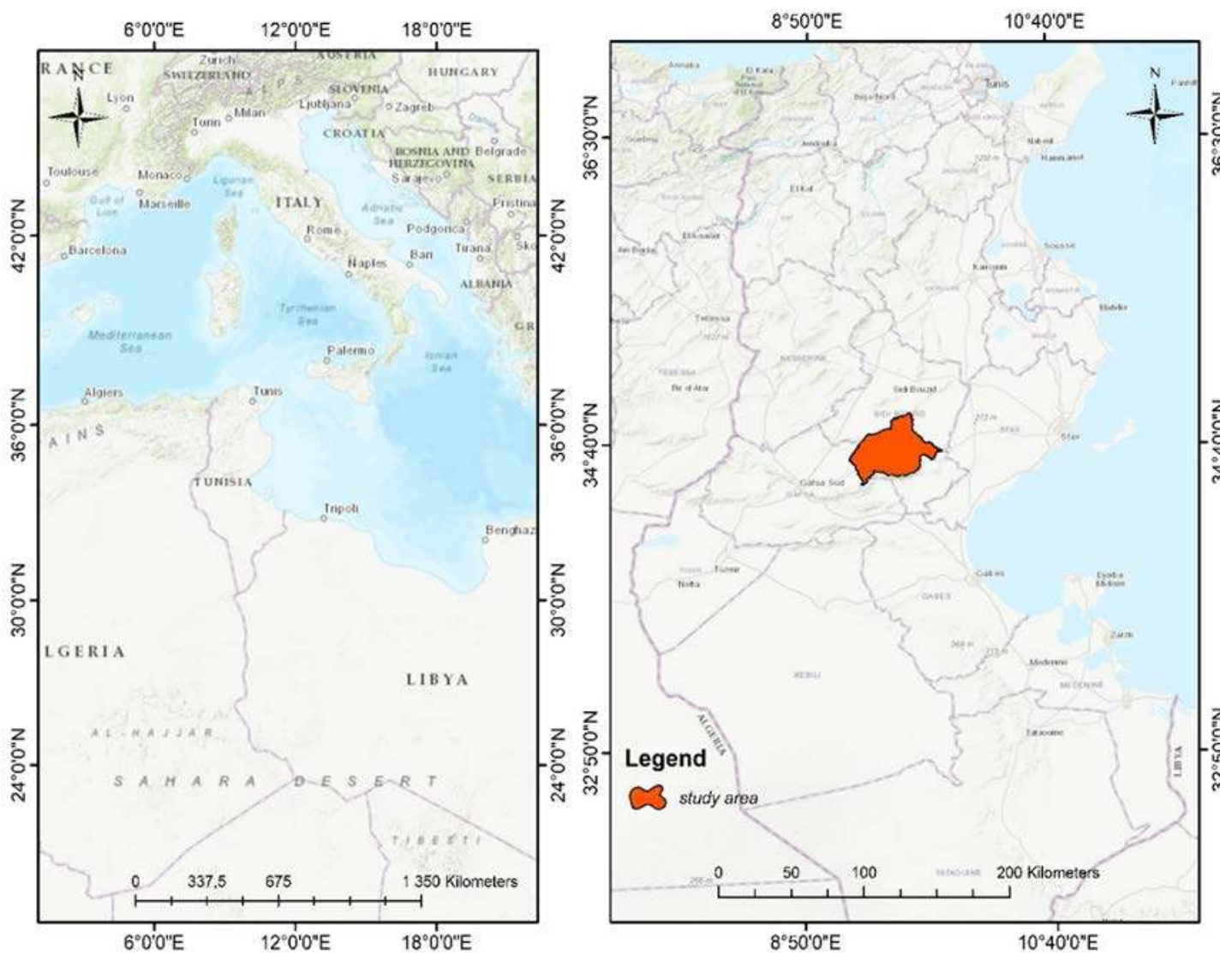

Figure 1 Location of the study area 


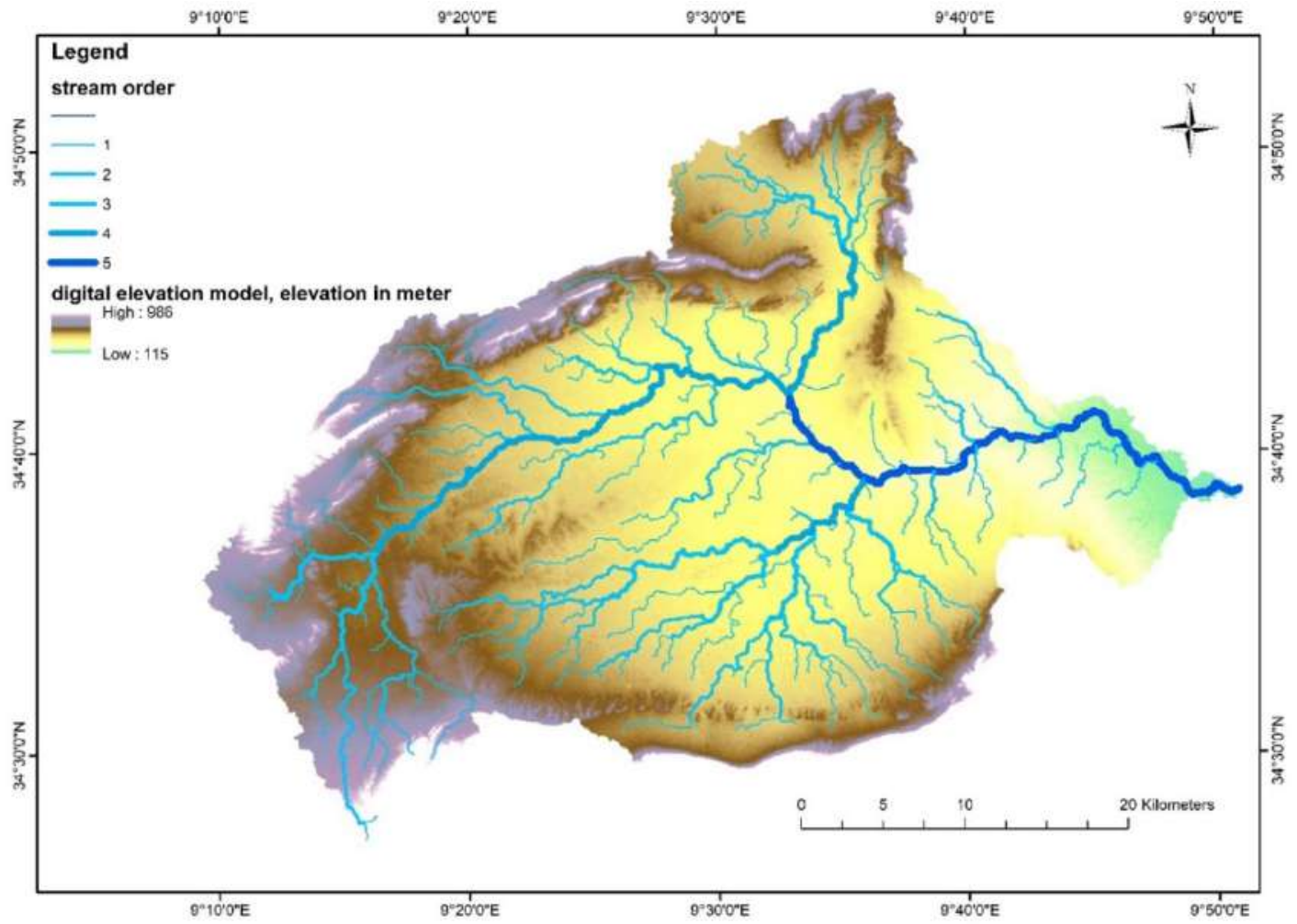

Figure 2 Digital elevation model and stream

The outcropping rocks on the reliefs are essentially Cretaceous limestone and dolomite except the reliefs of the east where they are composed by gypsum and clay-gypsum layers. Clay outcrops are particularly present in the south-eastern part of Dribika and Nadour of Triassic constitution. Neogene deposits (clay, conglomerate, sand) often occupy the northern and eastern piedmonts with gypsum or calcareous crusts. Inherited or actual sand accumulations litter the relief of the southern limit of the catchment. Most of the central plains are alluvial layers from the Upper Pleistocene and Holocene. The study area belongs mainly to the upper arid climate stage, a small part to the south-east to the cool lower arid and a band corresponding to the Majoura Mountain (north-west of the basin) belongs to the temperate lower semi-arid stage. The relief surrounding the watershed is covered by a degraded scrubland of Phoenicia juniper. While the western piedmonts are covered by an esparto steppe, the southern piedmont is the site of a sandy jujube steppe. The eastern and north-eastern gypsum lands are covered with halophile vegetation.

\section{Materials and methods}

Presentation of RUSLE model: This model consists of five independent parameters which, multiplied according to the following equation result in the final soil loss rate (Eq. 1) (Fig. 3).

$A=R \times K \times C \times P \times L \times S$

where, $A=$ annual rate of soil loss in tones $\times \mathrm{ha}^{-1} \times$ year $^{-1}, R=$ rainfall erosivity factor, $K=$ soil erodibility factor, $C=$ crop cover factor, $P=$ practice support factor, $L S=$ topography factor.

The rainfall erosivity factor $R$, as defined by Wischmeier and Smith (1978) (Eq. 2), means the rain kinetic energy $E$ multiplied by the maximum rainfall intensity $\left(I_{30}\right)$ for $30 \mathrm{~min}$. This index represents the potential erosive risks in a specific region. In our study, given the impossibility to apply the Wischmeier and Smith equation, we opted for the formula developed by Renard and Freimund (1994) based on the modified Fournier index (MFI) which establishes the relationship between the MFI and the $R$ factor with a high determination coefficient $\left(r^{2}=81\right)$ (Eq. 3a) (Renard and Freimund, 1994). The MFI reflects both annual and monthly average and 
will avoid overestimating of $R$ factor values in a region characterized principally by its aridity (Eq. 4) (Arnoldus, 1980). The MFI and $R$ factor were calculated on the rainfall data of 7 stations located around but also inside the catchment area, for the period from 2002 to 2011 . This period was chosen because it has no data gaps.

$R=\left(E_{c}\right) \times\left(I_{30}\right)$ (Wischmeier and Smith, 1978) (2) where, $R$ is the erosivity factor for an event in $\mathrm{MJ} \times$ $\mathrm{mm} \times \mathrm{ha}^{-1} \times \mathrm{hr}^{-1} \times$ year $^{-1}, E_{c}$ is the total rain kinetic energy in $\mathrm{MJ} / \mathrm{h}$ and $I_{30}$ is the maximum rain intensity in 30 minutes in $\mathrm{mm} / \mathrm{h}$.

$R=0.07397 \times F^{1.847}$ when $F<55 \mathrm{~mm}$

$R=95.77-6.081 F+0.477 \times F^{2}$ when $F>55 \mathrm{~mm}(\mathrm{~b})$

where $F$ is the Modified Fournier Index

$F=\sum_{i=1}^{12} \frac{(P i)^{2}}{P}$

where $P_{\mathrm{i}}$ is the monthly rainfall average and $P$ is the annual average.

The soil erodibility factor $K$ is a function of organic matter, texture, permeability and soil profile structure. The initial equation of Wischmeier et al., 1978 (Eq. 5) has often been used to define tables containing soil $k$ values. The higher this index, the higher the soil erosive potential. In our study we extracted the soil map from the Carte Agricole (agricultural map, digital database) of the ministry of agriculture. Then we assigned the $k$ values available in literature from Tunisia or elsewhere (Ben Cheikha et al., 2008; Andersson, 2010; Zante, 2003; Kort, 2013; Leguedois, 2003).

$K=A \times B \times C \times D \times 0.1317$

where:

$A=[0.2 \times 0.3 \exp (0.0256 \operatorname{sand}(1-\operatorname{silt} / 100))]$

$B=\left[\frac{\text { silt }}{\text { clay }+ \text { silt }}\right]^{0.2}$

$\left.C=\left[1.0-\frac{0.25 \text { clay }}{(\text { clay }+\operatorname{Exp}[(3.72-2.95 \text { clay })]}\right)\right]$

$D=\left[1.0-\frac{0.7 \text { sand } 1}{(\operatorname{sand} 1+\operatorname{Exp}[(-5.41+22.9 \text { sand } 1)])}\right]$

The topographic factor $L S$ is a function of both slope length $L$ and slope steepness $S$. It means the slope contribution to increase erosion potential in the study area. To obtain $L S$ value map we applied the following equations: McCool et al., 1987; Des- met et al., 1996 (Eq. 6). We used the $28 \mathrm{~m}$ resolution Astgdem digital elevation model. This choice was dictated by the relatively large area of the catchment but also the absence of a more detailed DEM covering the basin.

$L S=L \times S$

$L=\left(\frac{\lambda}{22.13}\right)^{m}$

$m=\frac{F}{1+F}$

$F=\frac{(\sin \beta \times 0.01745 / 0.0896)}{3(\sin \beta \times 0.01745)^{0.8}+0.56}$

$m$ =index of slope's length factor

$L_{(i, j)}=\frac{\left[A_{(i, j)}+D^{2}\right]^{m+1}-A_{(i, j)}^{m+1}}{x^{m} D^{m+2}(22.13)^{m}}$

where: $\beta=$ Slope layer in ArcGis (in degrees), $A=$ Flow accumulation layer (ArcGis), $D=$ grid cell size (meters), $X=$ coefficient that corrects the length of flow way through a raster cell.

S-factor

when $\tan \beta_{(i, j)}>0.09 \quad S_{(i, j)}=10.8 \sin \beta_{(i, j)}+0.03$

when $\tan \beta_{(i, j)} \geq 0.09 \quad S_{(i, j)}=16.8 \sin \beta_{(i, j)}-0.5$

Crop management factor $C$ refers to the role of vegetation in protecting soils from erosion. It includes both natural and cropland vegetation. Today, remote sensing makes it much easier to study crop cover. In our study we used a Sentinel_2_1C image with a resolution of $10 \mathrm{~m}$. Image processing and field confirmation allowed us to make a supervised classification. This has permitted us to have land use classes to which we have assigned the $C$ factor values from literature (Masson, 1971).

The conservation practice factor $P$ considers man-made facilities and agricultural practices (ploughing, crop rotation, etc.) used to reduce runoff and erosion. This factor varies from total protection (0) to no protection (1). In our study we firstly digitized conservation practices from Google Earth. Then we exported polygons to ArcGis where we integrated them into the class slope map in percentages. Afterwards we extracted and pasted them with the untreated area and assigned $P$ values to these polygons according to the slope classes. The untreated area was given a value of 1 . 


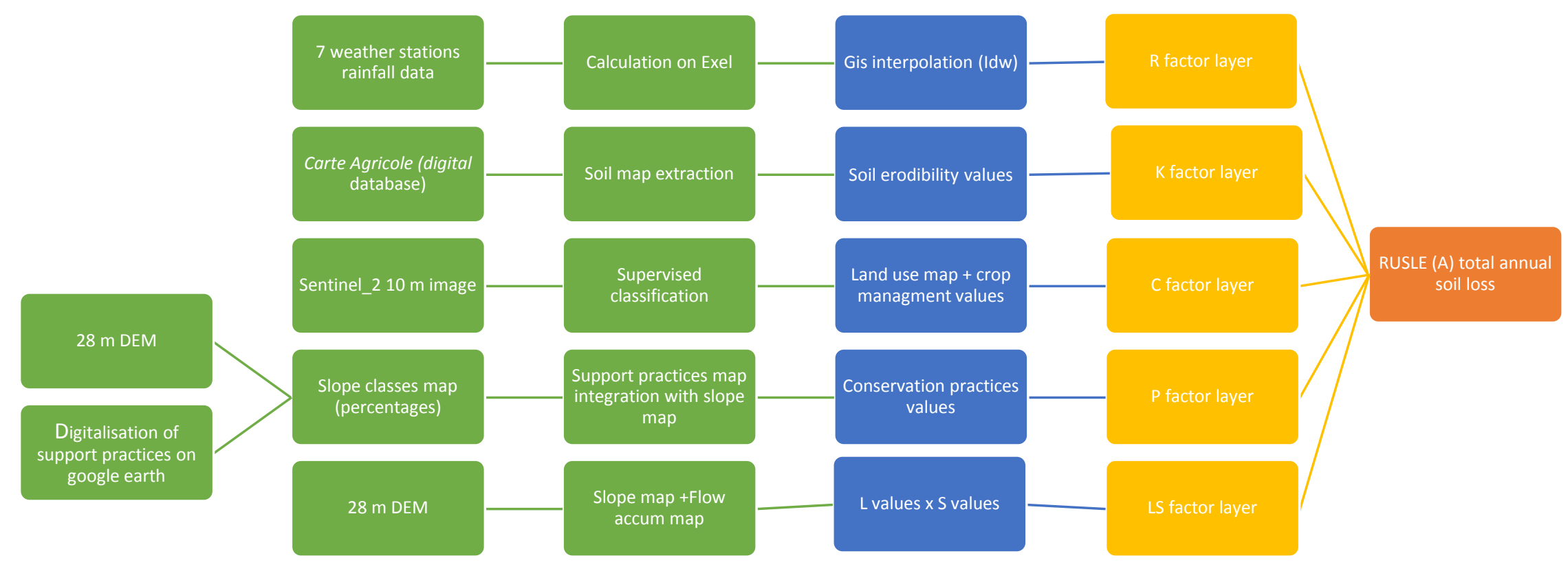

Figure 3 Methodology flow chart 


\section{Results and discussion}

After the data collection phase, we proceeded to calculate model factors, one by one, then to multiply them in the math algebra tool of the ArcGis software. The results are as follows:

- Rainfall erosivity factor $R$ : after interpolation with the Idw tool and extraction in the ArcGis software, the study region shows an $R$ factor evolving between 20.58 and $32.59 \mathrm{MJ} \times \mathrm{mm} \times \mathrm{ha}^{-1} \times \mathrm{hr}^{-1} \times$ year $^{-1}$ (Table 1) (Fig. 4). These values are very low com- pared to other regions but are consistent with their climate and the amount of rainfall the region receives. Moreover, some studies cite $R$ values comparable to these. They particularly are in concordance with the results of Zante et al., (2003). This author recorded for Abdessadok watershed (Tunisian dorsal, Siliana region, $345 \mathrm{~mm}$ ) values of 64 $\mathrm{MJ} \times \mathrm{mm} \times \mathrm{ha}^{-1} \times \mathrm{hr}^{-1} \times \mathrm{year}^{-1}$ as average with values of 25 for the dry year and $93 \mathrm{MJ} \times \mathrm{mm} \times \mathrm{ha}^{-1} \times \mathrm{hr}^{-1} \times \mathrm{yr}^{-1}$ for the very rainy year.

Table 1 Weather stations, annual rainfall average and $R$ factor for 2002-2011 period

\begin{tabular}{l|llccc}
\hline Stations & LONG & LAT & $\begin{array}{c}\text { Rainfall } \\
\text { Annual average } \mathbf{( m m )}\end{array}$ & $\begin{array}{c}\text { Modified } \\
\text { Fournier index }\end{array}$ & R factor \\
\hline Bir Ali & 10.095789 & 34.740684 & 186.68 & 20.61 & 19.77 \\
Skhira & 10.0699 & 34.299882 & 187.87 & 22.12 & 22.53 \\
Mezzouna & 9.84223 & 34.580594 & 182.79 & 21.90 & 22.13 \\
Meknassy & 9.602237 & 34.604781 & 197.52 & 21.06 & 20.59 \\
Bouzayane & 9.427244 & 34.573043 & 210.85 & 24.11 & 26.42 \\
Sidi Bouzid & 9.483061 & 35.037113 & 308.11 & 33.17 & 47.63 \\
Gafsa & 8.784391 & 34.422414 & 193.6 & 14.53 & 10.37 \\
\hline
\end{tabular}

- The soil erodibility factor $K$ : this factor was determined first by extracting the soil map as polygon files from the Carte Agricole (national agricultural mapping program) and then by assigning $K$ values from studies performed in Tunisia or elsewhere. According to experimental work by Dumas (1965), (Table 3), soils constituting the study area belong to soils with high erodibility and very high erodibility (between 0.04 and 0.075

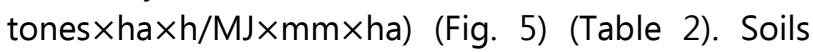
very sensitive to erosion are confined in the moun- tain belt surrounding the catchment. These are mainly raw mineral soils and low developed soils. But the rest of the land in the watershed is also composed of highly erodible soils. The spatial distribution of the different soil types shows the diversity of the formations occupying the basin. Thus, low developed soils are the most widespread in the catchment (33\%). Then we find complex soils with $15 \%$, followed by isohumic soils with $18 \%$ of the watershed. Raw mineral soils and rendzine occupy respectively $13 \%$ and $8 \%$ of the total surface.

Table 2 Soil types, $K$ factor values and sources

\begin{tabular}{l|lllc}
\hline Soil type & K factor values & ha & \% & Source \\
\hline Rendzine & 0.05 & 12394.2 & 8.42 & Ben cheikha et al.(2008) \\
Raw mineral soils & 0.075 & 19895.47 & 13.52 & Ben cheikha et al.(2008) \\
Low developed soils & 0.055 & 49720.27 & 33.80 & Ben cheikha et al.(2008) \\
Brown calcareous soils & 0.046 & 9699.305 & 6.59 & Ben cheikha et al.(2008) \\
Iso humic brown soils & 0.042 & 27289.38 & 18.55 & Kort (2013) \\
Halomorphic soils & 0.04 & 4620.358 & 3.14 & Kort (2013) \\
Complex soils & 0.05 & 22274.69 & 15.14 & Andersson (2010) \\
Stream bed & 0.046 & 1172.018 & 0.79 & Zante (2003) \\
\hline
\end{tabular}




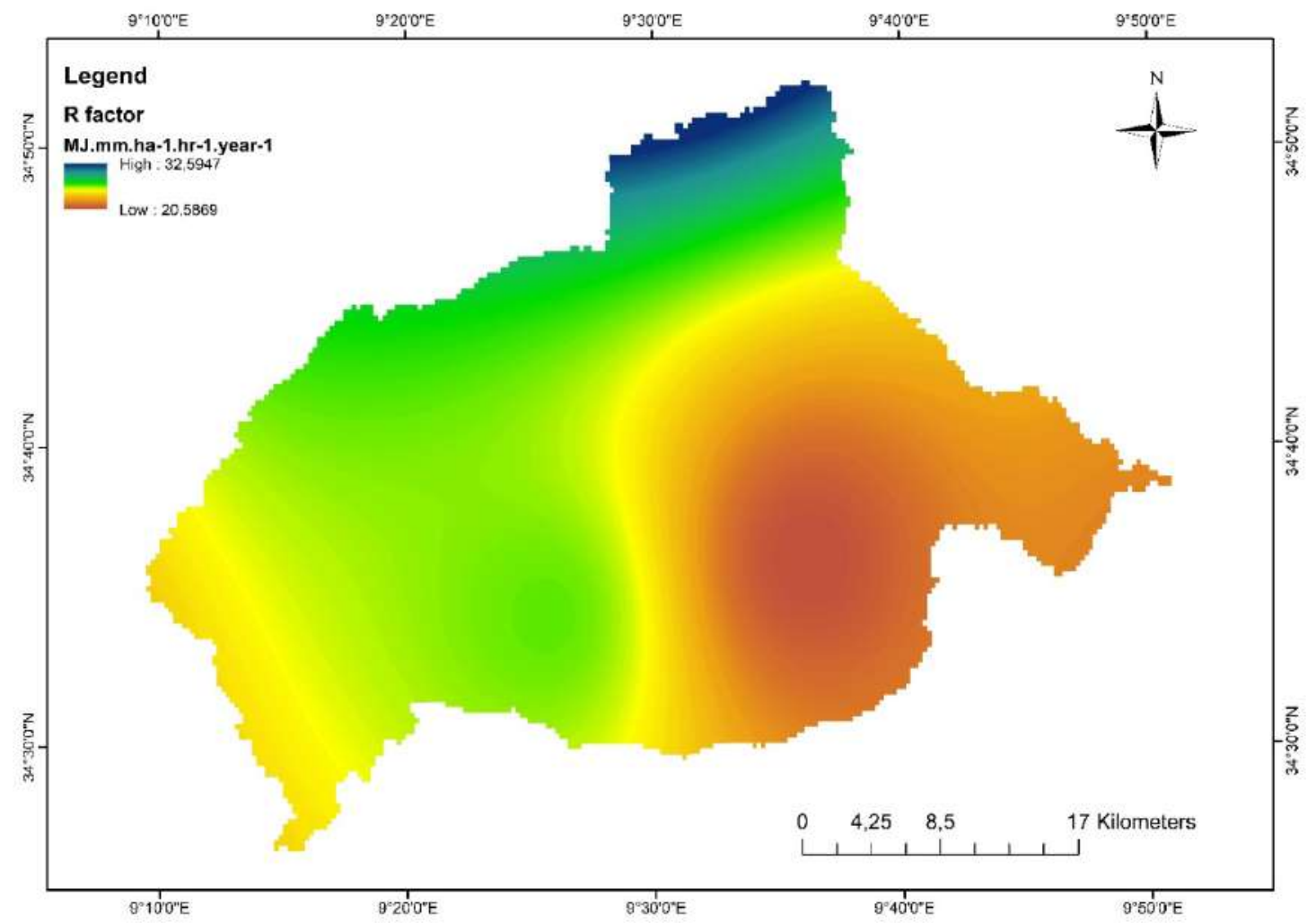

Figure $4 R$ factor

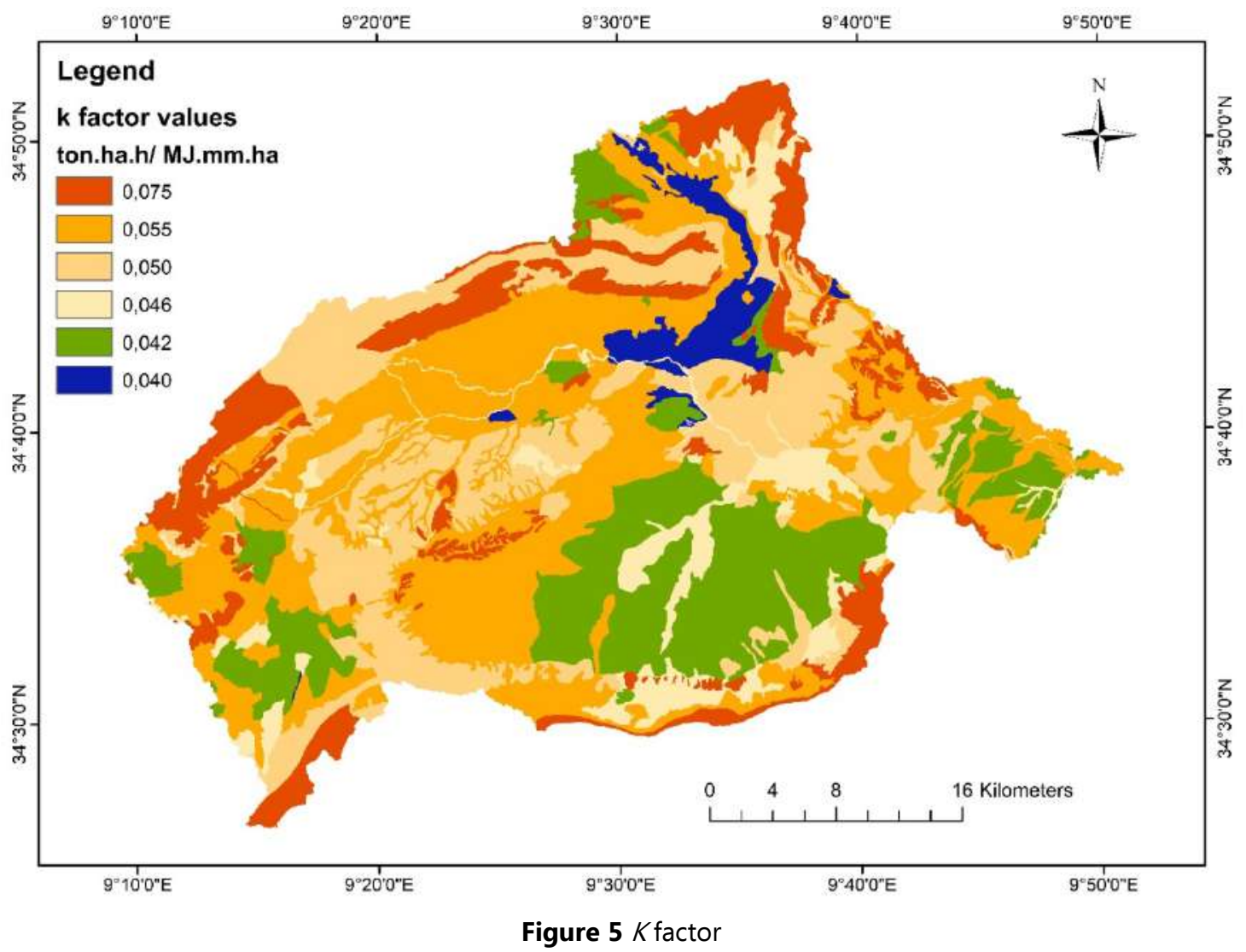




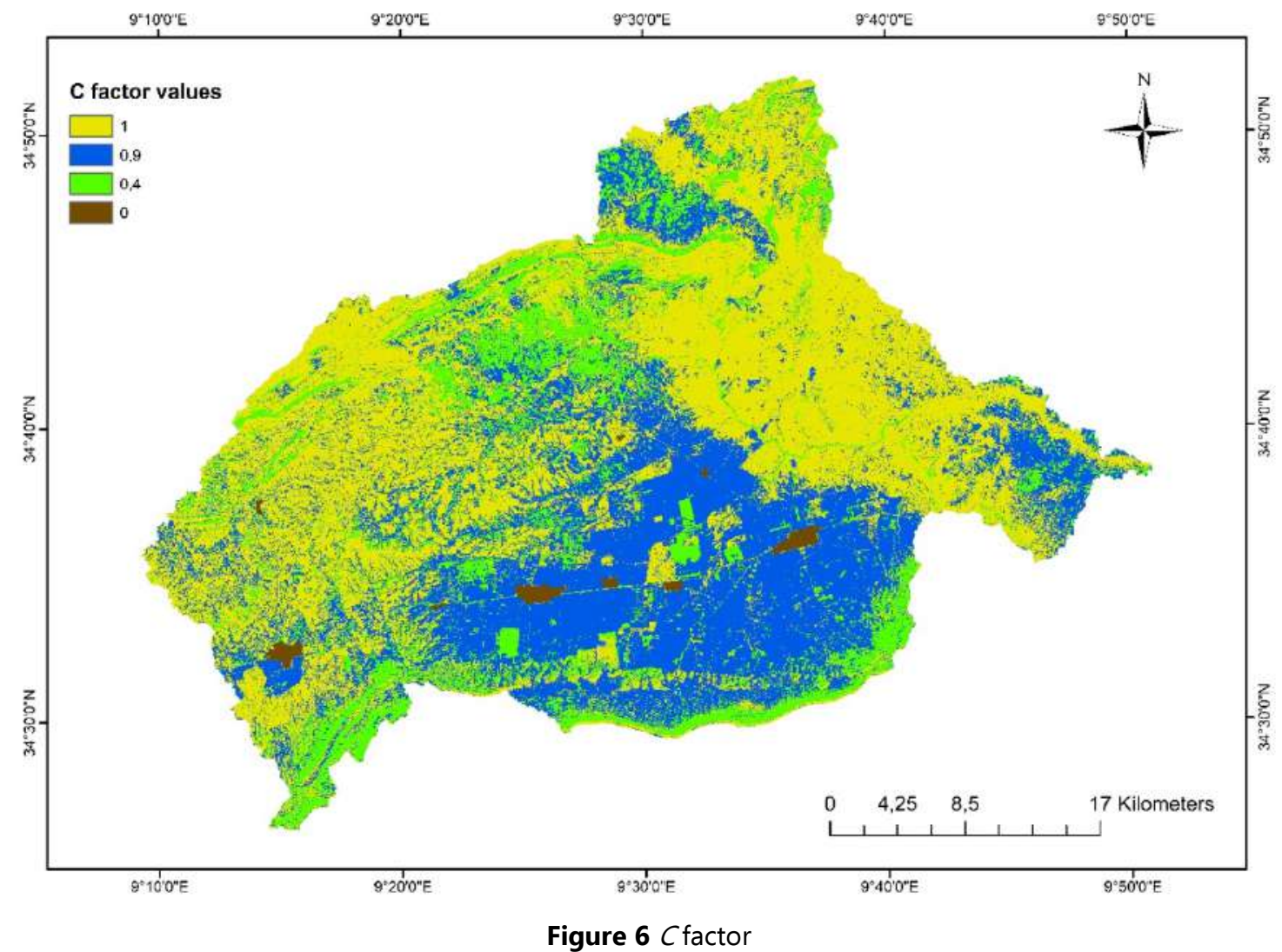

Table 3 Soil erodibility classes according to Dumas (1965) after conversion to SI units system (Foster et al., 1981)

\begin{tabular}{ll}
\hline Values classes & Erodibility classes \\
\hline $\mathrm{K}<0.0065$ & very lowly erodible soil \\
$0.0065<\mathrm{K}<0.0131$ & slightly erodible soil \\
$0.0131<\mathrm{K}<0.0263$ & moderately erodible soil \\
$0.0263<\mathrm{K}<0.0526$ & highly erodible soil \\
$0.0526<\mathrm{K}<0.079$ & very highly erodible soil \\
\hline
\end{tabular}

- Crop management factor $C$ : this factor was first determined from a Sentinel 2 satellite image classification and the identification of the different homogeneous land use zones. Then the $C$ values available in the literature were assigned to these areas (Masson, 1971) (Table 4). The following values are given: 0.9 for olive groves which occupy $35 \%$ of the catchment area, 0.4 for intensively cultivated areas, i.e. $15 \%$ of the catchment area, and 1 for bare soil which represents approximately half of the catchment area (Fig. 6) (Table 5).

- The conservation practices factor $P$. this factor was first created by digitizing the treated areas, essentially by contour benches from Google Earth. Then, polygons were integrated with slope map classified in percentages. Afterwards, they were extracted from the unprotected area. While the maximum value 1 has been assigned to these, the values of the treated areas depend on their slope class. Results are as follow: untreated area represents the major part of the watershed: $89 \%$. The remaining $10 \%$ has $P$ values oscillating between 0.55 and 0.9 (Fig. 8) (Table 6).

Table 4 C factor table according to Masson (1971)

\begin{tabular}{ll}
\hline Vegetation type & C factor \\
\hline Bare land, fallow land & 1 \\
Fruit arboriculture & 0.9 \\
Winter wheat & 0.7 \\
Cereal crop rotation & 0.4 \\
Forages & 0.2 \\
Cereal crop rotation + fodder & 0.1 to 0.01 \\
Improved pastures & 0.01 \\
\hline
\end{tabular}


Table 5 Crop management values and sources

\begin{tabular}{lcccc}
\hline Crop management & C factor values & ha & $\%$ & Source \\
\hline Bare soils, bare rocks & 1 & 71240.50154 & 48.44 & Masson (1971) \\
Olive groves & 0.9 & 51497.14704 & 35.01 & Masson (1971) \\
Irrigated crops and intensive plots & 0.4 & 23343.46525 & 15.87 & Masson (1971) \\
Built-up areas & 0 & 971.1252788 & 0.66 & - \\
\hline
\end{tabular}

Table 6 factor values and sources

\begin{tabular}{ccccc}
\hline Slope classes & $\begin{array}{c}P \text { factor values } \\
\text { (contouring) }\end{array}$ & ha & $\%$ & Source \\
\hline $0-7$ & 0.55 & 9232.803 & 6.27 & Shin (1999) \\
$7-11.3$ & 0.6 & 4069.721 & 2.76 & Shin (1999) \\
$11.3-17.6$ & 0.8 & 2005.117 & 1.36 & Shin (1999) \\
$17.6-26.8$ & 0.9 & 467.7729 & 0.31 & Shin (1999) \\
$>26.8$ & 1 & 131296.4 & 89.27 & Shin (1999) \\
\hline
\end{tabular}

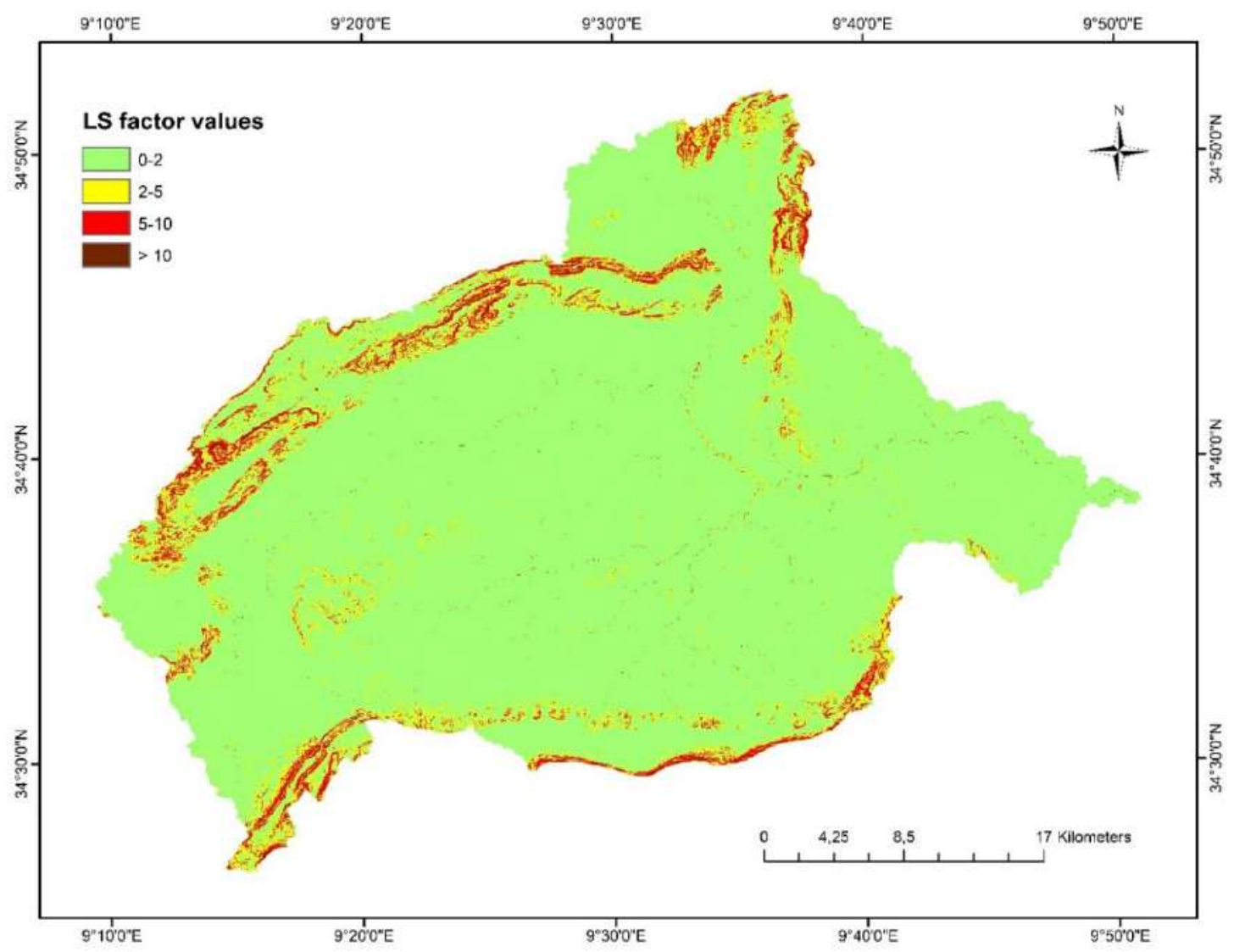

Figure $7 L S$ factor 


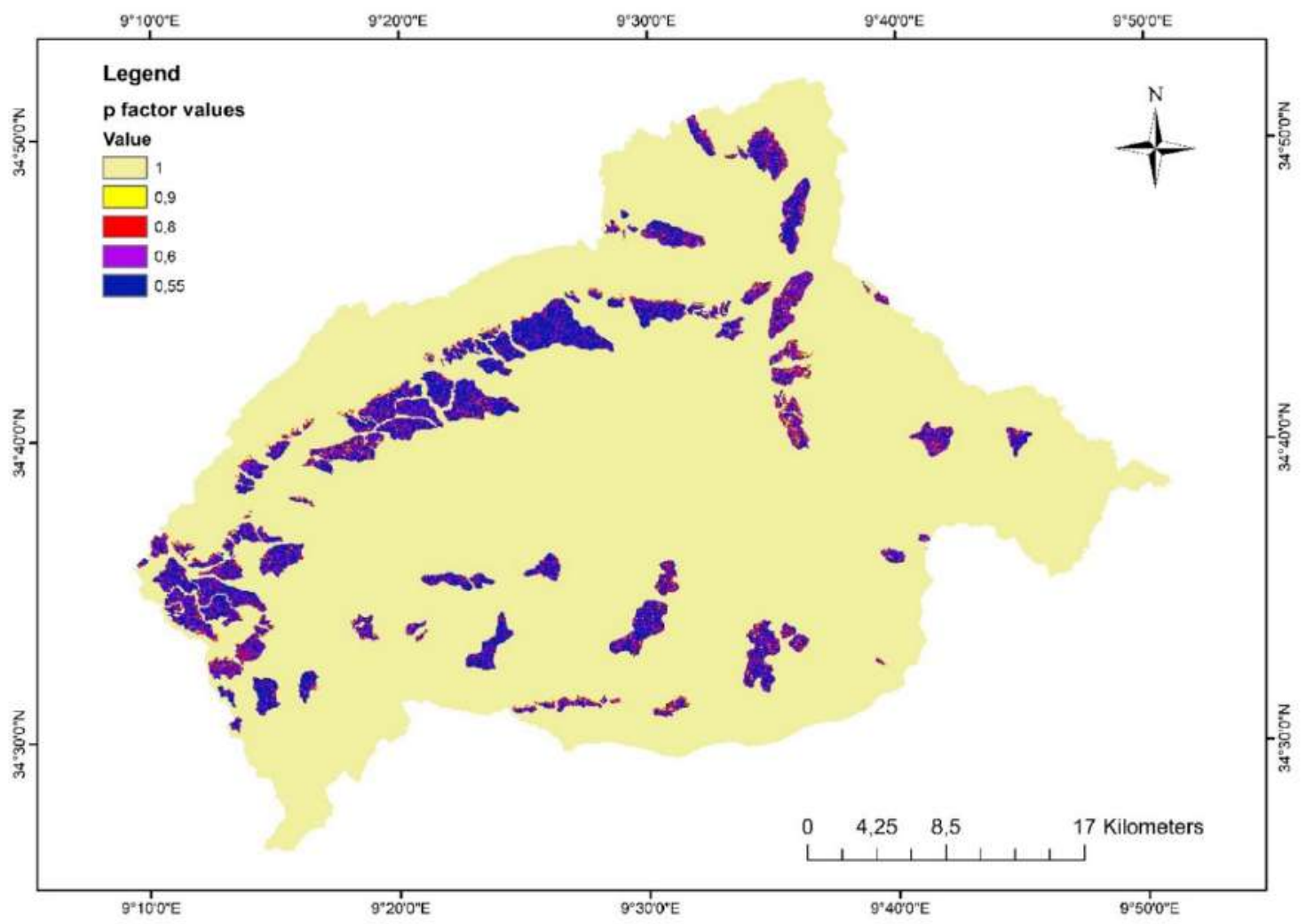

Figure $8 P$ factor

- The slope length and steepness factor $L S$ : The watershed values vary between 0 and 836 and they are closely linked to the slope map values, i.e. the mountain areas are those with the highest $L S$ values, whereas the central plains have the lowest (Fig. 7). The spatial distribution of the $L S$ factor shows that most of the catchment (87\%) has values below 2 , followed by the moderate slopes, low-reliefs and plateau (7\%) which have values between 2 and 5 (Table 7). Then we find the areas of steep slopes of the mountainous border (3.79\%) which have values between 5 and 10. Mountain cornices and main rivers $(0.41 \%)$ have values greater than 10 .

Table 7 Classified $L S$ factor values

\begin{tabular}{lll}
\hline $\begin{array}{l}\text { LS factor } \\
\text { values classes }\end{array}$ & Area in ha & $\%$ \\
\hline $0-2$ & 129405.10 & 87.98 \\
$2-5$ & 11495.49 & 7.82 \\
$5-10$ & 5570.16 & 3.79 \\
$>10$ & 607.65 & 0.41 \\
\hline
\end{tabular}

- RUSLE annual total erosion

Seen as a whole, annual soil loss values are evolving between 0 and 731 tones $\times$ ha $^{-1} \times$ year $^{-1}$ with an average erosion of 3.84 and a standard deviation of 5.08 tones $\times$ ha $^{-1} \times$ year $^{-1}$.

Erosion map in stretched values based on standard deviation clearly shows a location of elevated values on the mountains of the north, northwest and secondarily of the south of the watershed (Fig. 9). This is logical since the regions mentioned include important mountain systems with narrow inter-mountain depressions and often steep slopes.

Representation of erosion values under the standard RUSLE classification shows the 5-15 tones $\times$ ha $^{-1} \times$ year $^{-1}$ class as the most characteristic of mountainous regions (4.93\%) while the 0 to 1 class is the most widespread in the watershed terrain (78\%) followed by the 1 to 5 tones $\times$ ha $^{-1} \times$ year $^{-1}$ class (15.53\%) (Fig. 10) (Table 8).

But when we use the Masson (1971) classification for the semi-arid regions of Tunisia we can see more details in erosion spatial distribution (Fig. 11) (Table 9). Therefore, lands experiencing erosion between 0 and 2 tones $\times$ ha $^{-1} \times$ year $^{-1}$ represent the 
major part of the basin (86.34\%). Those losing between 2 and 5 tones $\times$ ha $^{-1} \times$ year $^{-1}$ represent $8.02 \%$, followed by lands suffering soil loss between 5 and 10 tones $\times$ ha $^{-1} \times y e a r^{-1}$ (5.41\%). The most critical erosion (above 10 ) concerns only $1.92 \%$. If we combine the two central classes, we obtain 13.43 (19448.48 ha) of the lands affected by erosion between 2 and 10 tones $\times \mathrm{ha}^{-1} \times$ year $^{-1}$.
Table 8 Soil annual loss under standard classes

\begin{tabular}{ccc}
\hline $\begin{array}{c}\text { Erosion classes } \\
\text { (tones } \times \text { ha }^{-\mathbf{1}} \times \text { year }^{-\mathbf{1}} \text { ) }\end{array}$ & ha & \% \\
\hline $0-1$ & 114139.27 & 78.84 \\
$1-5$ & 22477.60 & 15.53 \\
$5-15$ & 7143.24 & 4.93 \\
$15-50$ & 1009.31 & 0.70 \\
$50-200$ & 10.54 & 0.01 \\
$>200$ & 1.27 & 0.0008 \\
\hline
\end{tabular}

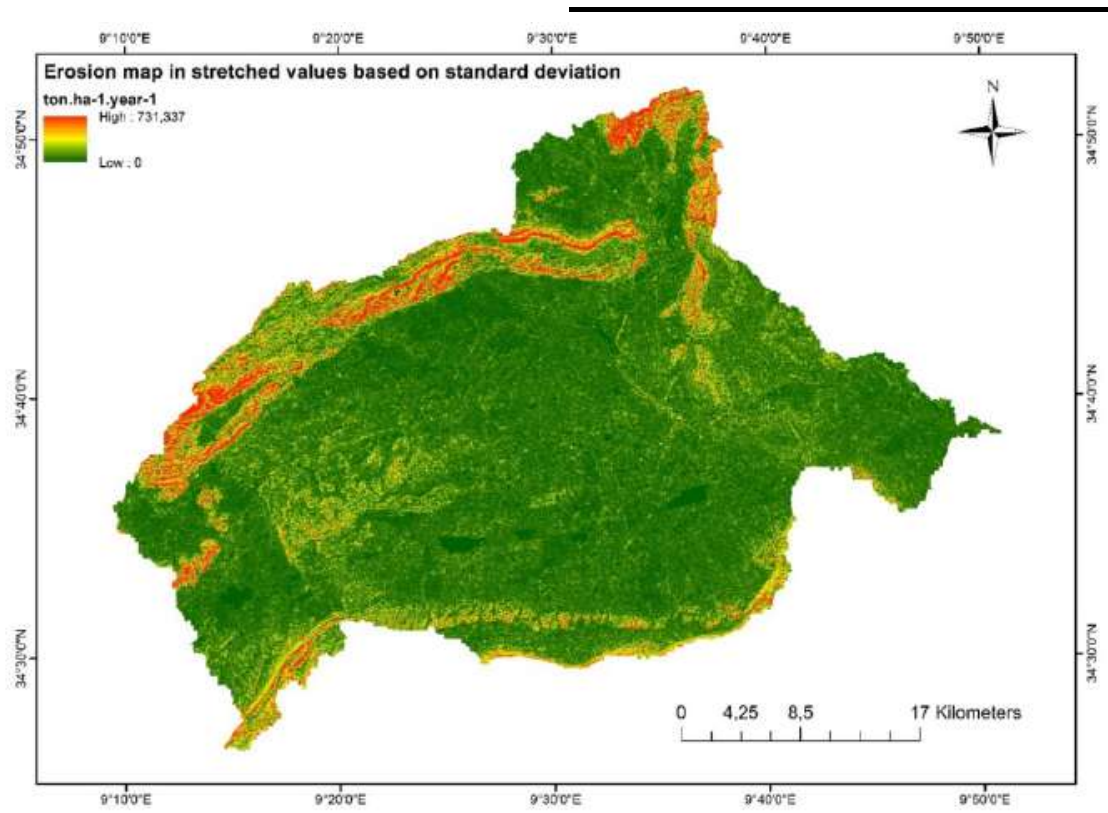

Figure 9 Erosion map in stretched values based on standard deviation

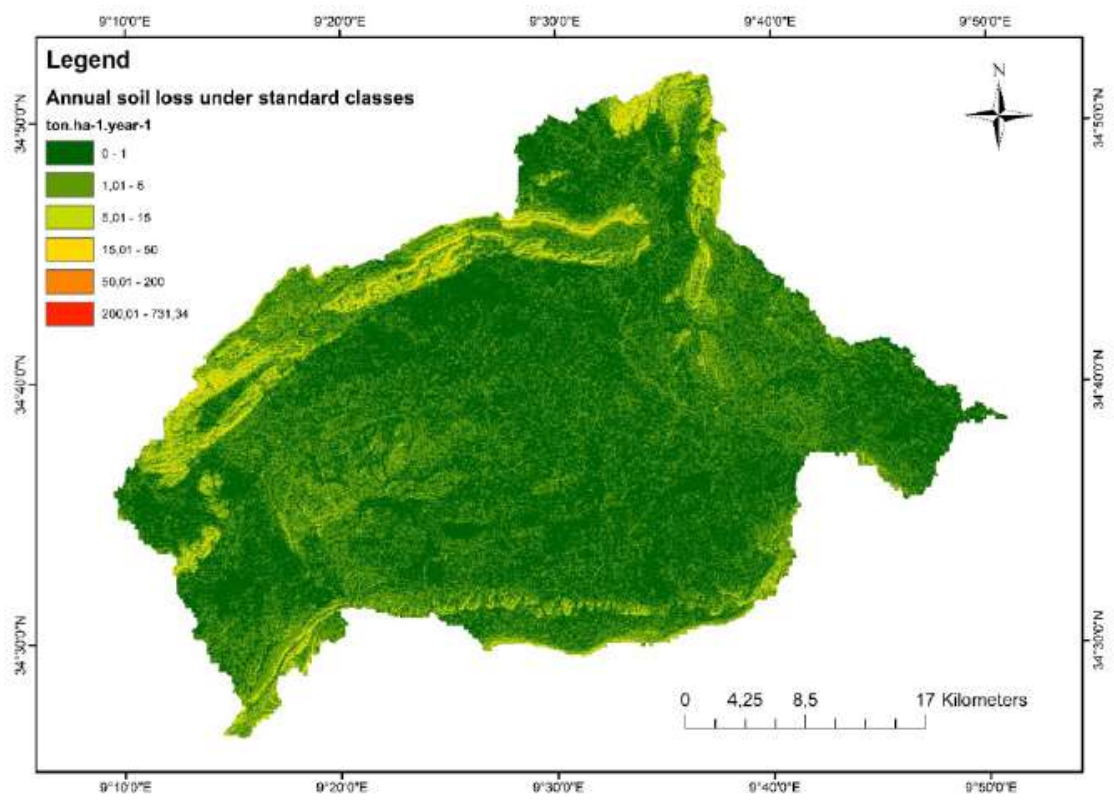

Figure 10 Annual soil loss under standard classes 


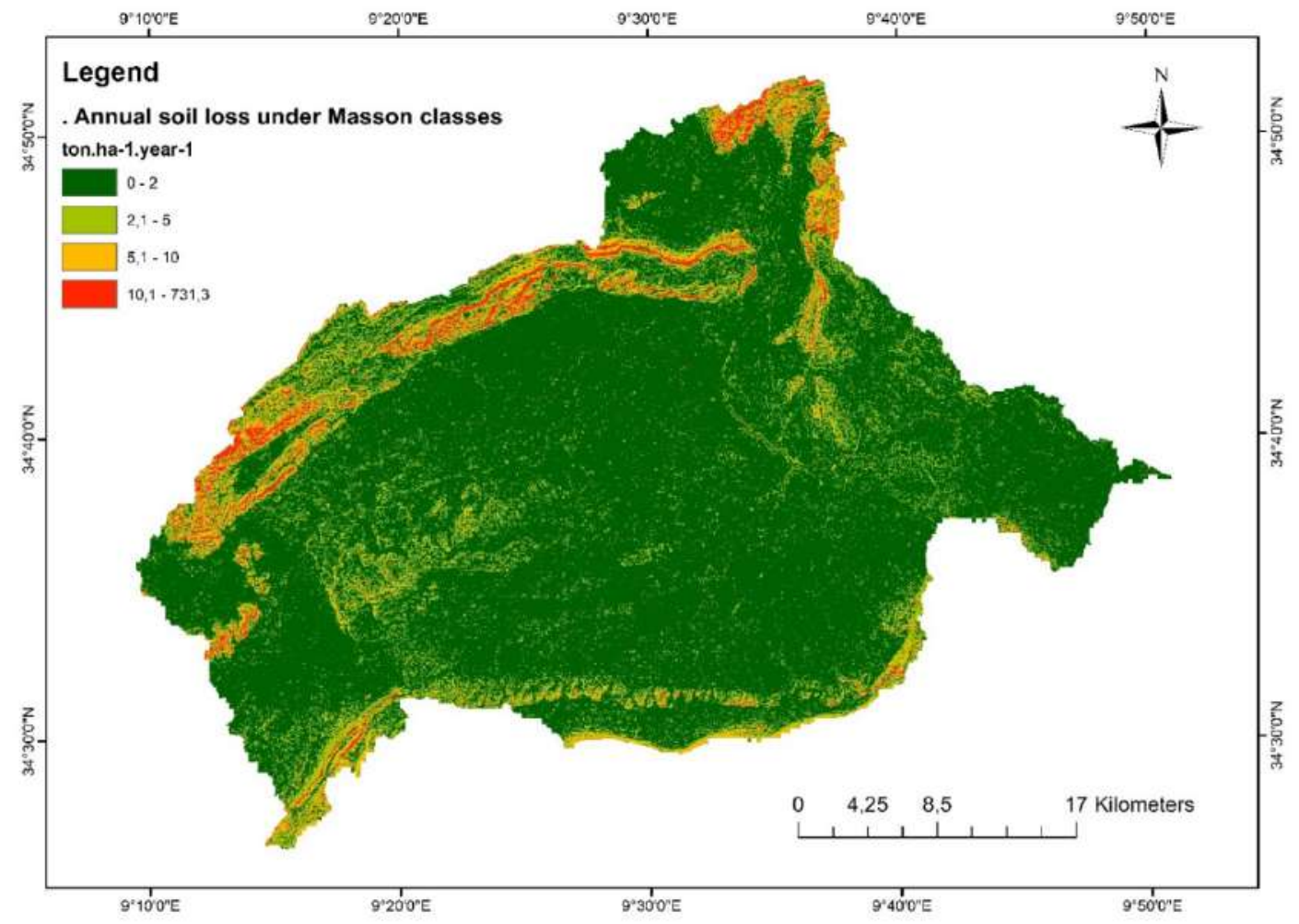

Figure 11 Annual soil loss under Masson (1971) classes for Tunisian semi-arid lands

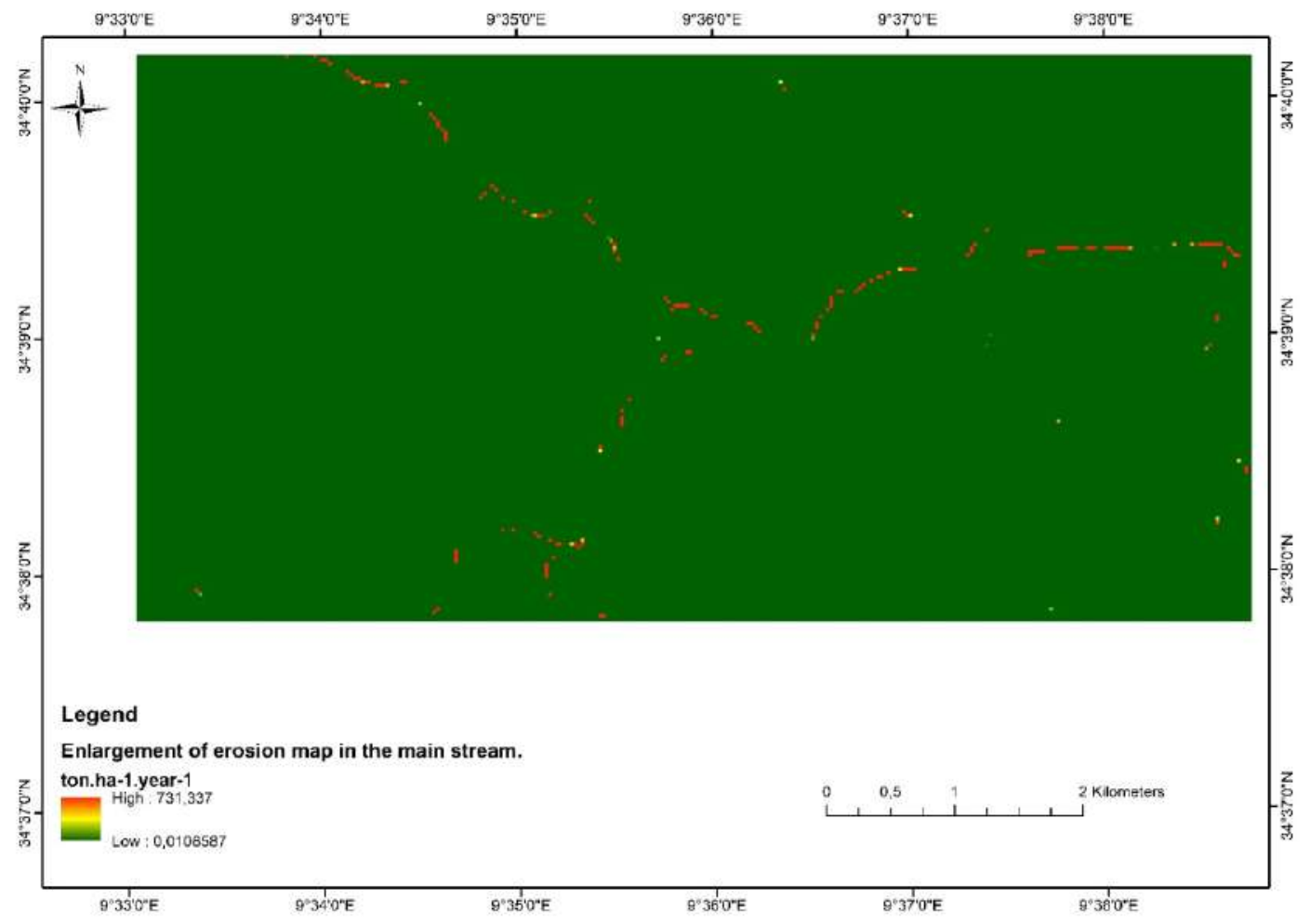

Figure 2 Enlargement of erosion map in the main stream 


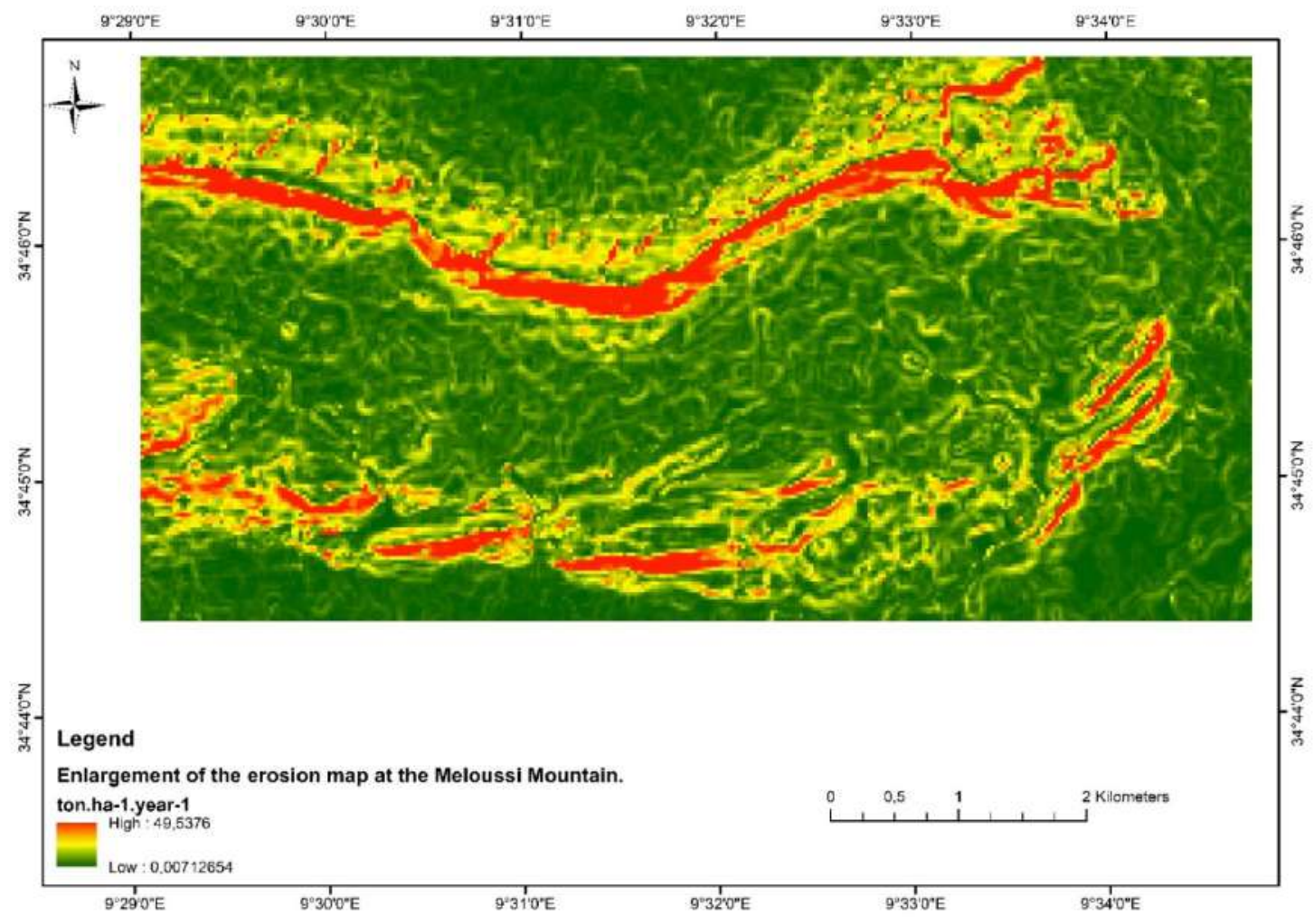

Figure 3 Enlargement of the erosion map at the Meloussi Mountain

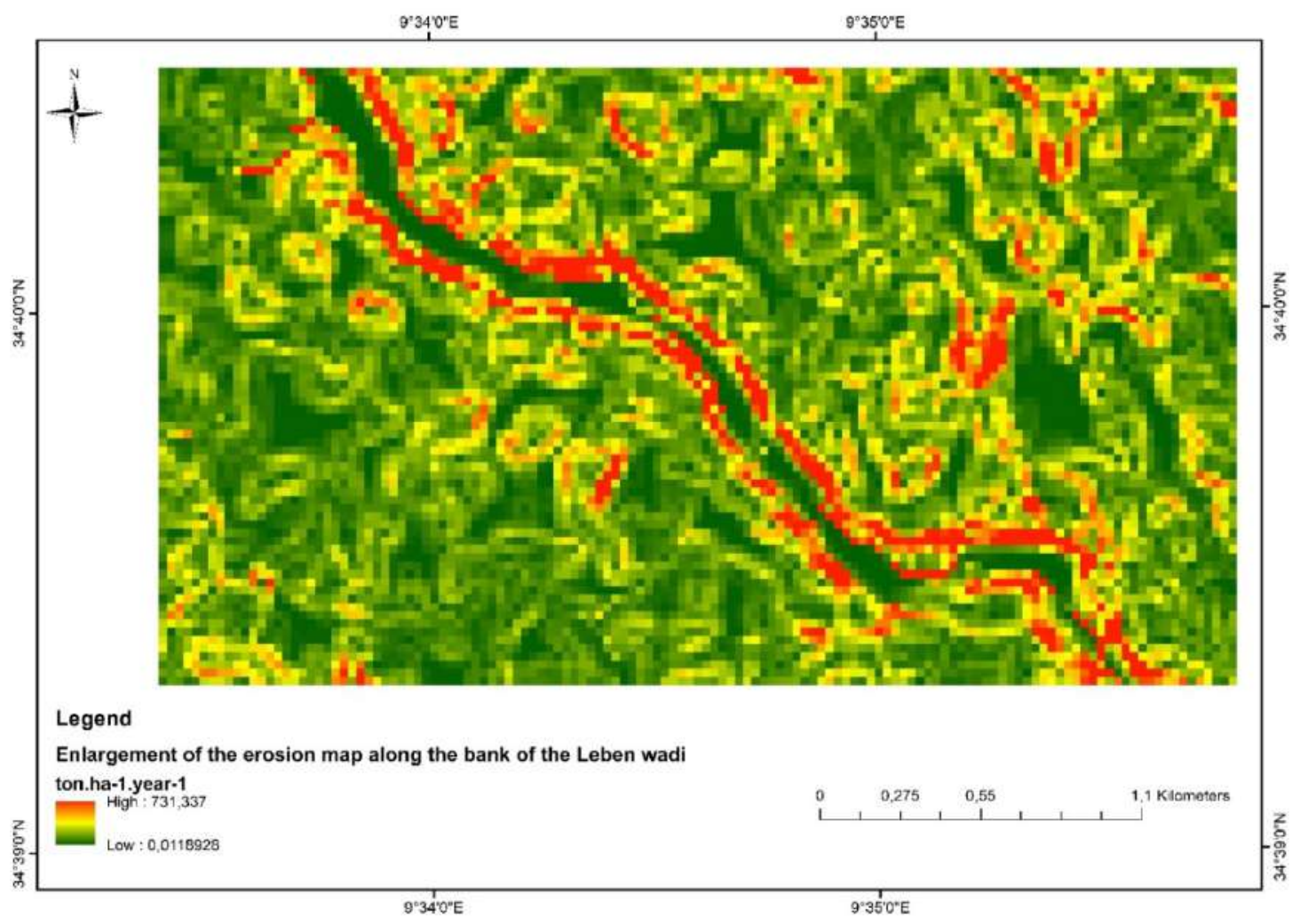

Figure 4 Enlargement of the erosion map along the Leben banks 
Table 9 Annual soil loss under Masson (1971) classes for Tunisian semi-arid lands

\begin{tabular}{lcc}
\hline $\begin{array}{l}\text { Erosion classes } \\
\left(\text { tones } \times \text { ha }^{-1} \times \text { year }^{-1} \text { ) }\right.\end{array}$ & ha & $\%$ \\
\hline $0-2$ & 124998.74 & 86.34 \\
$2-5$ & 11618.13 & 8.02 \\
$5-10$ & 7830.35 & 5.41 \\
$>10$ & 2780.37 & 1.92 \\
\hline
\end{tabular}

The relatively high erosion values recorded on the relief of the catchment borders are clearly related to the presence of soil types with very high erodibility ( $K$ above 0.052$)$ which are raw mineral soils, low-developed soils and soils with high erodibility (rendzine). They are also explained by the often high $L S$ values recorded there. On the other hand, reliefs of the catchment margins are rarely cultivated or covered by a vegetal cover. On the contrary, they are experiencing significant overgrazing due to a livestock that is inappropriate with attempts to reforest and improve grazing areas remaining below requirements. Protection against erosion is almost absent in the mountains surrounding the catchment. Reforestation does not seem to succeed and slopes are often denuded denouncing multiple failures: inefficiency of reforestation and protection efforts but also multiple and repeated aggressions by abusive overgrazing.
Comparison with previous studies on erosion quantification may be interesting if authors had used similar formulas and same unit system. Therefore Zante et al., (2003) obtained in the Abdessadok watershed (Tunisian dorsal, Siliana region, $345 \mathrm{~mm}$ ) an average soil loss of 4.12 tones $\times$ ha $^{-1} \times$ year $^{-1}$ with a minimum value of 1.75 (the driest year) and a maximum value of 6.03 (the wettest year). These values seem to be concordant with the values recorded here given the similarities between the two catchments.

Moreover, Albergel et al. (2003) reported, at the end of the Hydromed project (study of water erosion in selected basins in the Mediterranean area) and during the annual observation of soil losses, values in the order of 1.8 tones $\times$ ha $^{-1} \times$ year $^{-1}$ in the Gouazine catchment (Tunisian dorsal, jebel Bargou, $400 \mathrm{~mm}), 12.2$ tones $\times \mathrm{ha}^{-1} \times \mathrm{xyear}^{-1}$ in the Mrichet watershed (Tunisian dorsal, jebel Bargou, $450 \mathrm{~mm}$ ), 17.5 tones $\times$ ha $^{-1} \times$ year $^{-1}$ in the Es Senega basin (central Tunisia, Sbiba region, $250 \mathrm{~mm}$ ), 24.2 tones $\times \mathrm{ha}^{-}$ ${ }^{1} \times$ year $^{-1}$ in the Fidh Ali catchment (central Tunisia, Kairouan region, $300 \mathrm{~mm}$ ) and 32 tones $\times \mathrm{ha}^{-1} \times \mathrm{year}^{-1}$ in the Kamech basin in northeast Tunisia (Table 10).

Later, Ben Chaika et al. (2008) recorded in the Jannet watershed (Tunisian dorsal, Siliana region, $400 \mathrm{~mm}$ ) a value of 14.8 tones $\times \mathrm{ha}^{-1} \times \mathrm{year}^{-1}$ for an average year, with values in the order of 6.5 tones $\times \mathrm{ha}^{-1} \times \mathrm{year}^{-1}$ for a dry year and a value of 20 tones $\times \mathrm{ha}^{-1} \times \mathrm{year}^{-1}$ for a very wet year.

Table 10 Soil loss in some catchments in Tunisia after Alberger et al., (2003)

\begin{tabular}{|c|c|c|c|c|}
\hline Watersheds & Location & $\begin{array}{l}\text { Catchment } \\
\text { area (ha) }\end{array}$ & $\begin{array}{l}\text { Year of } \\
\text { survey }\end{array}$ & $\begin{array}{c}\text { Soil loss } \\
\left(\text { tones } \times \text { ha }^{-1} \times \text { year }^{-1}\right)\end{array}$ \\
\hline El Gouazine & $\begin{array}{c}\text { Central Tunisia, valley in alluvium Pleistocene crusts. } \\
\text { (Isohyet } 400 \mathrm{~mm} \text { ) }\end{array}$ & 1810 & 1990 & 1.8 \\
\hline Es Sénéga & $\begin{array}{c}\text { Central Tunisia, Cretaceous Mountains. Limestone and } \\
\text { gypsum marls (Isohyet } 250 \mathrm{~mm} \text { ) }\end{array}$ & 363 & 1991 & 17.5 \\
\hline Fidh Ali & $\begin{array}{l}\text { Central Tunisia, Eocene anticline. Marls } \\
\text { gypsum and lumachelles (Isohyet } 400 \mathrm{~mm} \text { ) }\end{array}$ & 238 & 1991 & 24.2 \\
\hline Kamech & $\begin{array}{l}\text { Central Tunisia, Cap Bon Anticline. } \\
\text { Limestone, sandstone and marl (Isohyet } 650 \mathrm{~mm} \text { ) }\end{array}$ & 245.5 & 1993 & 32.0 \\
\hline M'Richet & $\begin{array}{l}\text { Central Tunisia, Bargou anticline. Marls } \\
\text { and Cretaceous limestone (Isohyet } 450 \mathrm{~mm} \text { ) }\end{array}$ & 158 & 1991 & 12.2 \\
\hline
\end{tabular}

Andresson (2010) obtained values of 11.4 and 24.5 tones $\times$ ha $^{-1} \times$ year $^{-1}$ respectively in the Mrichet and Sabine basins. Gaubi et al., (2017) recorded in the Lebna catchment (North-East of Tunisia) a value of 24 tones $\times \mathrm{ha}^{-1} \times \mathrm{year}^{-1}$. The disparities in erosion values mentioned here are mainly attributable to geographical variations in the $R$ factor. Indeed, rainfall in Tunisia is increasing towards the northwest. 
The study of the final erosion map shows that the main streams are not only considered to be areas of high erosion but also have the highest rates of erosion in the basin (Fig. 12). Indeed, if the mountainous sectors record values between 0 and 49 tones $\times$ ha $^{-1} \times$ year $^{-1}$, (Fig. 13) main streams have values ranging from $0-731$ tones $\times \mathrm{ha}^{-1} \times \mathrm{year}^{-1}$, the highest in the catchment as shown on the enlargement maps legend. This can be explained by the role of $L S$ factor based on slope accumulation and particularly flow accumulation from upstream to downstream of the catchment area. This means that at the level of the main streams and especially their downstream segments, the flows accumulation is maximum, resulting in a maximum of erosion. Thus, the model revision and $L S$ factor formulas multiplication have resulted in a consequent improvement in of erosion assessment. Similarly, the enlargement shows that in watercourses the pixels with the most erosion values most often correspond to the banks more than the bed (Fig. 14). This is related to the abrupt change in elevation and slope recorded by the model interpreting it as a flow and material movement.

\section{Conclusion}

In this study, the objective was to use the RUSLE prediction model to quantify erosion in the Leben catchment. While $R$ factor values are significantly low (between 20.58 and $32.59 \mathrm{MJ} \times \mathrm{mm} \times \mathrm{ha}^{-1} \times \mathrm{hr}^{-}$ ${ }^{1} \times$ year $^{-1}$ ), the $K$ factor values are substantially high or very high (between 0.04 and 0.075 tones $\times$ ha $\times$ h/MJ $\times m m \times h a)$. Similarly, the watershed is dominated by bare soils (48\%) or olive groves (35\%), which do not provide much soil coverage; soil conservation practices have only concerned the piedmont sectors in the catchment. The $L S$ factor, closely related to slope maps, reveals mountainous areas as more susceptible to erosion.

Superposition of the different model factors allowed us to compute erosion values and revealed erosion rates ranging between 0 and 731 tones $\times$ ha ${ }^{1} \times$ year $^{-1}$ with an average erosion of 3.84 tones $\times$ ha

${ }^{1} \times y e a r^{-1}$. The relatively elevated rates of erosion are mainly found in the relief surrounding the catchment because of the high values of slopes, the skeletal soils which often compose them, but also be- cause of absence of protection, reforestation or crop management. This means that the process of relief erosion that began in the Tertiary Era continues, taking advantage of soil and vegetation degradation and overgrazing. It means also that, if the mountain slopes are not protected and reforested, erosion will not decrease in the watershed while protection of the piedmont remains relative.

Comparison with previous studies carried out in Tunisia shows similarities in the results with some of them considering the geographical variation of the $R$ factor. Analysis of the results at the pixel level showed that the streams and especially their banks record the highest erosion values and this was related to the flow accumulation in the downstream sections.

\section{References}

Albergel J, Pepin Y, Nasri S, Boufaroua M. 2003. Érosion et transport solide dans des petits bassins-versants méditerranéens. "Hydrology of the mediterranean and semi-arid regions". Proceedings of an international symposium held at Montpellier, April 2003, IASH Publ., 278: 373-9.

Andersson L. 2010. Soil loss estimation based on the USLE/GIS approach through small catchments - a minor field study in Tunisia. PhD Dissertation, Division of Water Resources Engineering, Department of Building and Environmental Technology, Lund University, Sweden. http://lup.lub.lu.se/student-papers/record/1709494/file/1709495.pdf (Accessed 13.07.2018)

Arnoldus HM. 1980. An approximation of the rainfall factor in the Universal Soil Loss Equation. In: De Boodt M, Gabriel D. (eds.): Assessment of erosion. John Wiley and Sons, Inc. Chichester, West Sussex, UK. 127-132.

Ben Cheikha L, Gueddari M. 2008. Le bassin versant du Jannet (Tunisie): évaluation des risques d'érosion hydrique, (The Jannet catchment area (Tunisia): water erosion risk assessment). Mappemonde, $\mathbf{9 0}$. https://mappemondearchive.mgm.fr/num18/articles/ art08202.html (Accessed 13.07.2018)

Copernicus Open Access hub. Sentinel-2 1c 10m resolutionimagery.

https://scihub.copernicus.eu/dhus/\#/home (Accessed 13.07.2018)

Desmet PJJ, Govers G. 1996. A GIS procedure for automatically calculating the USLE LS factor on topo- 
graphically complex landscape units. Journal of Soil and Water Conservation, 51: 427-433.

Dumas J. 1965. Relation entre l'érodibilité des sols et leurs caractéristiques analytiques. Cahier ORSTOM, Série pédologie. 3(4): 307-333.

ESRI 2011. ArcGIS Desktop: Release 10. Redlands, CA: Environmental Systems Research Institute.

Foster GR, McCool DK, Renard KG, Moldenhauer WC. 1981. Conversion of the universal soil loss equation to SI metric units. Journal of soil and water conservation, 36(6): 355-359.

Gaubi I, Chaabani A, Ben Mammou A, Hamza MH. 2017. A GIS-based soil erosion prediction using the Revised Universal Soil Loss Equation (RUSLE) (Lebna watershed, Cap Bon, Tunisia). Nat Hazards, 86: 219-239 http://agri.ckcest.cn/ass/NK005-20170410004.pdf (Accessed 13.07.2018).

Kort A. 2013. Soil erosion assessment in the dryland areas of Bolivia using the RUSLE 3D model. Master thesis, Wageningen University, 62p.

Leguedois S. Mécanismes de l'érosion diffuse des sols. Modélisation du transfert et de l'évolution granulométrique des fragments de terre érodés. Sciences de la Terre, Université d'Orléans, 2003.

Masson JM. 1971. L'érosion des sols par l'eau en climat méditerranéen. Méthode expérimentale pour l'étude des quantités érodées à l'échelle du champ (Soil erosion by water in Mediterranean climate. Experimental method for the study of field scale eroded quantities). Thèse, Université des Sciences et Techniques de Languedoc, $213 \mathrm{p}$.

McCool DK, Brown LC, Foster GR. 1987. Revised slope steepness factor for the Universal Soil Loss Equation. Transactions of the American Society of Agricultural Engineers, 30: 1387-1396.

Ministry of Agriculture 2001. La carte agricole (the agricultural map), governorate of Sidi Bouzid.

NASA Land Processes Distributed Active Archive Center (LP DAAC), USGS/ astgdem

https://earthexplorer.usgs.gov/.
Renard KG, Foster GR, Weesies GA, McCool DK, Yoder DC. 1997. Predicting soil erosion by water: a guide to conservation planning with the Revised Universal Soil Loss Equation. U.S. Department of Agriculture, Agriculture Handbook 703, 384 pp.

https://www.tucson.ars.ag.gov/unit/publications/PDFfiles/ 1132.pdf (Accessed 13.07.2018).

Renard KG, Freimund JR. 1994. Using monthly precipitation data to estimate the $\mathrm{R}$ factor in the revised USLE. Journal of Hydrology, 157: 287-306.

https://www.google.fr/url?sa =t\&rct=j\&q=\&esrc=s\&sourc $\mathrm{e}=$ web\&cd = 1\&ved =2ahUKEwijrsiO89PeAhVEIVAKHfTAxIQFjAAegQICRAC\&url=https\%3A\%2F\%2Fpdfs.se manticscholar.org\%2F667f\%2F0a294b72faef8c2badd 533c760f46c21d021.pdf\&usg=AOvVaw1YtSUIvXHA8 oLI4Arca0eu

Shin GJ. 1999. The analysis of soil erosion analysis in watershed using GIS. PhD dissertation, Department of Civil Engineering, Gang-Won National University.

Water Resources Department of the Governorate of Sidi Bouzid. Données pluviométriques du gouvernorat de sidi Bouzid (Rainfall data of the governorate of Sidi Bouzid) (Personal communication).

Wischmeier WH, Smith DD. 1965. Predicting rainfall erosion loss from cropland east of the Rocky Mountains. USDA Agricultural Handbook no. 282. 47p. https://www.tucson.ars.ag.gov/unit/Publications/PDFf iles/501.pdf (Accessed 13.07.2018).

Wischmeier WH, Smith DD. 1978. Predicting rainfall erosion losses. A guide to conservation planning. The USDA Agricultural Handbook no. 537, Maryland.

Zante P, Collinet J, Leclerc G. 2003. Cartographie des risques érosifs sur le bassin versant de la retenue collinaire d'Abdessadok (nord dorsale tunisienne), Institut de Recherche pour développement, Tunisie (Mapping of erosive risks in the Abdessadok hill basin (north of the Tunisian dorsal region). Research Institute for Development, Tunisia).

https://agritrop.cirad.fr/553389/1/document_553389. pdf (Accessed 13.07.2018). 